\title{
The Role of Nicorandil in the Management of Chronic Coronary Syndromes in the Gulf Region
}

\author{
Kevin Cheng (D) - Khaldoon Alhumood · Fayez El Shaer (D) • \\ Ranil De Silva
}

Received: September 11, 2020 / Accepted: November 19, 2020 / Published online: December 22, 2020

(c) The Author(s) 2020

\begin{abstract}
Chronic coronary syndromes (CCS) and stable angina are a growing clinical burden worldwide. This is of particular concern in the Gulf region given its high prevalence of cardiovascular risk factors, especially diabetes mellitus and smoking. Despite recommendations on the use of first- and second-line anti-anginal medication, management challenges remain. Current guidelines for pharmacologic treatment are not determined by the range of pathophysiological mechanisms of ischaemia and consequent angina, which may occur either in isolation or co-exist. In this article, we highlight the need to improve knowledge of the epidemiology of chronic
\end{abstract}

K. Cheng · R. De Silva $(\bowtie)$

Specialist Angina Service, Royal Brompton and Harefield NHS Foundation Trust, London, UK

e-mail: r.desilva@imperial.ac.uk

K. Cheng · R. De Silva

Vascular Science Department, National Heart and Lung Institute, London, UK

K. Alhumood

Al Adan Hospital, Safat, Kuwait

F. El Shaer

Department of Cardiac Sciences, King Fahad Cardiac Center, College of Medicine, King Saud University, Riyadh, Saudi Arabia

F. El Shaer

National Heart Institute, Cairo, Egypt coronary syndromes in the Middle East and Gulf region, and the need for studies of stratified pharmacologic approaches to improve symptomatic angina and quality of life in the large and growing number of patients with coronary artery disease from this region. We discuss the role of nicorandil, currently recommended as a second-line antianginal drug in CCS patients, and suggest that this may be a particularly useful add-on therapy for patients in the Gulf region.

Keywords: Chronic coronary syndrome; Gulf region; Nicorandil; Nitrates; Stable angina

\section{Key Summary Points}

CCS is a growing clinical burden worldwide, particularly in the Gulf region.

Current guideline recommendations for anti-anginal escalation have a limited evidence base.

Nitrates are frequently used for the treatment of CCS but have their limitations.

Nicorandil is a useful therapeutic option offering vasodilatory and cardioprotective effects.

Nicorandil has a contemporary randomised evidence base and a favourable clinical profile. 


\section{DIGITAL FEATURES}

This article is published with digital features to facilitate understanding of the article. You can access the digital features on the article's associated Figshare page. To view digital features for this article go to https://doi.org/10.6084/m9. figshare.13135805.

\section{INTRODUCTION}

Chronic coronary syndromes (CCS) and symptomatic stable angina pectoris are a growing clinical burden worldwide. This is especially the case in the Gulf region due to the high prevalence of coronary artery disease (CAD) making the use of optimal anti-anginal therapy of paramount importance in this population. Despite evidence showing that anti-anginal therapy improves quality of life, physicians often encounter challenges with individualising anti-anginal medication choices, especially when guideline-directed algorithms either inadequately control symptoms or are not tolerated. This may in part be addressed by adopting an approach of stratifying treatment choices according to the mechanism(s) of ischaemia operating in individual patients. In this review, we discuss the high burden of cardiovascular disease, current treatment landscape in the Middle East and Gulf region in the context of current international guidelines. We focus on the management of patients with symptomatic stable angina pectoris as a major subgroup of CCS, and highlight the potential benefits of nicorandil in managing CCS in this region.

\section{CLINICAL PRESENTATION}

The 2019 European Society of Cardiology (ESC) Guidelines for the diagnosis and management of CCS sought to capture the dynamic nature of stable CAD and its varied clinical presentations. The guidelines differentiate six categories of patients with suspected or established CCS [1]:
- Patients with suspected CAD and 'stable' anginal symptoms, and/or dyspnoea

- Patients with new onset heart failure or left ventricular dysfunction and suspected CAD

- Asymptomatic and symptomatic patients with stabilised symptoms $<1$ year after acute coronary syndrome (ACS) or with recent revascularisation

- Patients with angina and suspected vasospastic or microvascular disease

- Asymptomatic patients in whom CAD is detected at screening

This review will focus on patients who are symptomatic with 'stable' anginal symptoms in the setting of epicardial CAD, coronary microvascular dysfunction and vasospastic angina. Patients with stable angina pectoris experience episodes of reversible mismatch of myocardial oxygen supply and demand, usually in association with exercise, emotion or other stressors [2]. Patients with symptomatic stable angina pectoris need to be differentiated from those with unstable angina [1].

\section{EPIDEMIOLOGY}

\section{High Burden of Cardiovascular Disease}

Cardiovascular disease (CVD) remains the leading cause of death globally. The World Health Organization (WHO) estimated that, in 2016, 17.9 million people died from CVD, accounting for $31 \%$ of all mortality worldwide. Atherosclerotic diseases account for $\sim 85 \%$ of CVD mortality, principally due to myocardial infarction and stroke [3]. The Global Burden of Disease 2015 study estimated that there were 422.7 million cases of CVD worldwide, with ischaemic heart disease (IHD) the leading cause of death (8.9 million deaths) [4].

The burden of CVD is rising, particularly in low- and middle-income countries in which $75 \%$ of global CVD mortality occurs [5]. In lowand middle-income countries in particular, mortality is disproportionately high due to larger population sizes and the increasing prevalence of traditional cardiovascular risk factors, such as poor diet, physical inactivity, obesity, 
tobacco use, diabetes mellitus (DM), hypertension and hyperlipidaemia.

The Gulf region bears a particularly heavy healthcare burden from CAD. A communitybased study of 17,232 participants in Saudi Arabia found a CAD prevalence of 5.5\% [6]. The WHO estimated that, of the total mortality from non-communicable diseases in the countries within the Gulf Cooperation Council, CVD accounted for 23-49\% [7]. The Middle East has the lowest age for first presentation with acute myocardial infarction (median age 51 years) and the highest proportion of acute myocardial infarction under 40 years of age (11.2\%) [8]. This median age of presentation is 12 years lower than in Western Europe. Systematic reviews have confirmed the high prevalence of cardiovascular risk factors in the Middle East, in particular, obesity (24.5\%), DM (10.5\%), hypertension (21.7\%) and smoking (15.6\%) $[9,10]$. Of note, while smoking has declined in most Western countries from the late 1980s and 1990s, tobacco consumption has increased in the majority of Middle Eastern countries and is expected to rise further, particularly in young men [11]. The association between high rates of smoking in younger men and premature ACS has already been demonstrated in the Middle East and North Africa [12]. As a result, the number of patients with CCS and symptomatic angina pectoris can be expected to rise.

\section{Need For Gulf Region-Specific Data on CCS}

There are few data reporting the prevalence of CCS in the Middle East, with most estimates of disease burden extrapolated from ACS cohorts. The contemporary prospeCtive observational LongitudinAl RegIstry oF patients with stable coronary arterY disease (CLARIFY) provides the most recent regional data [13]. CLARIFY enrolled 32,105 patients with CCS from 45 countries worldwide between 2009-2010 and followed them for 2 years. It included 1511 patients from the Middle East and Gulf region. These patients experienced the highest prevalence of DM and elevated body mass index, despite a low prevalence of positive family history of CAD. Rates of anti-anginal use were as follows: $\beta$-blockers, $87.5 \%$; calcium channel blockers, 23.9\%; ivabradine, 5.2\%; nitrates or other anti-anginal drug, 32.8\%.

Despite the increasing burden of disease, randomised controlled trials (RCTs) or highquality registry data for anti-anginal drugs in the Middle East and Gulf region are not available. Health economic analyses of CCS management in the Gulf region are also scarce. A prospective observational study in Saudi Arabia of patients diagnosed or suspected of having IHD estimated the direct medical costs associated with hospitalisation and subsequent diagnosis of stable angina as US\$9064 (average length of stay, 6.5 days) [14]. Further studies are needed to address these important and growing unmet clinical needs of patients in the Middle East and Gulf regions.

\section{IMPACT OF DIABETES MELLITUS (DM)}

DM is estimated to have a prevalence of 410 million people globally, of whom 90\% have type $2 \mathrm{DM}$. This is a particularly severe issue in the Gulf region where the prevalence is consistently greater than the global average and has been dramatically increasing over the past 20 years, driven predominantly by increasing obesity $[15,16]$. The prevalence of type $2 \mathrm{DM}$ in Saudi Arabia has increased from $\sim 4 \%$ in the 1980 s to $\sim 25 \%$ in 2015 and is expected to almost double by 2035 [17]. Diagnosis is often delayed, with $40.3 \%$ of patients meeting diagnostic criteria being unaware of the diagnosis, resulting in suboptimal glycaemic control [18] and high rates of complications $[15,19]$.

The Gulf locals with Acute Coronary Syndrome Events (Gulf COAST) registry, a prospective, multinational, longitudinal, observational cohort study of Gulf citizens admitted with a diagnosis of ACS provides contemporary evidence of the regional burden of DM on cardiovascular mortality [20]: $53.3 \%$ of patients with ACS had DM in whom in-hospital, 30-day and 1-year mortality were significantly higher compared to non-diabetics. Patients with angina and concomitant DM also represent a challenging group to manage as they typically have 
more diffuse and extensive CAD, coronary microvascular dysfunction, and a greater burden of symptomatic angina than those without DM [21-23]. Given the increasing prevalence of DM and its impact on cardiovascular health in the Gulf region, improved detection, mitigation of cardiovascular risk and anti-anginal treatment are of paramount importance in this highrisk and challenging population.

\section{MANAGEMENT CHALLENGES}

Symptomatic angina pectoris may be caused by several ischaemic mechanisms, each of which can coexist. Understanding the relative contributions of each of these mechanisms within an individual patient can provide a rational approach for stratified selection of anti-anginal drug therapy. These include flow limitation due to epicardial coronary stenosis from obstructive CAD, coronary microvascular dysfunction and vasospasm [24-26]. A comprehensive review of anti-anginal drug therapy is beyond the scope of this report and we would refer the reader to current guidelines [1] and contemporary reviews of anti-anginal drugs [24, 25]. In the following sections, we have focussed on the role of nicorandil in the management in the CCS, in particular to highlight features of this drug which may address some of the particular challenges clinicians in the Gulf region face when managing patients with CCS and symptomatic angina pectoris.

\section{Stratified Selection of Anti-anginal Drug Therapy}

The choice of anti-anginal drug strategy depends on patient-related factors (mechanisms of ischaemia, haemodynamics, tolerability, drug interactions), physician experience, drug availability and cost [27]. The ESC 2019 CCS guidelines represent a significant advance, but a limitation remains in that they continue to recommend an algorithmic tiered approach to selection of anti-anginal drugs, which is not based on the results of appropriately powered randomised placebo-controlled trials, and further do not explicitly recommend drug choices based on the mechanism(s) of ischaemia operating in an individual patient [28, 29]. Ferrari et al. have previously argued that classification into first- and second-line drugs is not supported by a definitive evidence base [24, 25]. The recommended algorithm for combining multiple anti-anginal drugs is based predominantly on expert opinion rather than considering a formal stratification according to the underlying mechanism(s) of angina (Table 1). A recent comprehensive systematic review of medical treatment of angina revealed only 72 RCTs comparing two anti-anginals (total $n=7034$ ) between 1964 to the present. Only 13 studies evaluated between 100-300 patients with more than 50 patients per group to allow for meaningful comparisons between groups. "Second-line" drugs, however, have a stronger contemporary evidence base [30-32].

Given the lack of robust evidence showing superiority of any given anti-anginal drug, a more rational and personalised approach should be adopted that tailors the use of antianginal drug combinations according to physiological factors such as haemodynamics, mechanisms of ischaemia and comorbidities [24]. Recent guidelines also do not explicitly recommend treatment algorithms to be tailored according to the pathophysiological mechanism(s) causing ischaemia and symptoms in any given individual patient. This would seem an intuitive and rational approach, the principle of which is supported by recent studies such as the CorMicA trial [33].

\section{Lack of Improved Cardiovascular Outcomes with Anti-anginals}

No anti-anginal drug has been shown to improve cardiovascular mortality in symptomatic stable angina pectoris. Contemporary data from the CLARIFY and REACH registries have failed to demonstrate a reduction in allcause death in patients on $\beta$-blockers $[25,34]$. Calcium channel blockers do not improve mortality regardless of history of myocardial infarction. A double-blind placebo-controlled RCT of ivabradine $(n=19,102)$ in stable CAD, in patients without heart failure, did not reduce 
Table 1 ESC and ACC/AHA guidelines on anti-ischaemic drugs in stable coronary artery disease $[1,121]$

\begin{tabular}{|c|c|c|c|c|c|}
\hline $\begin{array}{l}\text { ESC } \\
\text { recommendations }\end{array}$ & \multicolumn{3}{|c|}{ Treatment option } & Class & Level \\
\hline \multirow[t]{3}{*}{ First line } & \multicolumn{3}{|c|}{$\beta$-blockers and/or calcium channel blockers to control heart rate and symptoms } & I & A \\
\hline & \multicolumn{3}{|c|}{$\begin{array}{l}\text { If symptoms not controlled on a } \beta \text {-blocker or a calcium channel blocker, the } \\
\text { combination of a } \beta \text {-blocker and a dihydropyridine calcium channel blocker should } \\
\text { be considered }\end{array}$} & IIa & $\mathrm{C}$ \\
\hline & \multicolumn{3}{|c|}{$\begin{array}{l}\text { Initial first-line treatment with a } \beta \text {-blocker and a dihydropyridine calcium channel } \\
\text { blocker should be considered }\end{array}$} & IIa & $\mathrm{B}$ \\
\hline \multirow[t]{3}{*}{ Second line } & \multicolumn{3}{|c|}{$\begin{array}{l}\text { Long-acting nitrates should be considered when initial therapy with a } \beta \text {-blocker and/or } \\
\text { a non-dihydropyridine calcium channel blocker is contraindicated, poorly tolerated } \\
\text { or inadequate in controlling symptoms }\end{array}$} & IIa & $\mathrm{B}$ \\
\hline & \multicolumn{3}{|c|}{$\begin{array}{l}\text { Nicorandil, ranolazine, ivabradine or trimetazidine should be considered to reduced } \\
\text { angina frequency and improve exercise tolerance in those who cannot tolerate, have } \\
\text { contraindications to, or whose symptoms are not controlled by } \beta \text {-blockers, calcium } \\
\text { channel blockers and long-acting nitrates }\end{array}$} & IIb & $\mathrm{B}$ \\
\hline & \multicolumn{3}{|c|}{$\begin{array}{l}\text { In selected patients, the combination of a } \beta \text {-blocker or a calcium channel blocker with } \\
\text { second-line drugs (nicorandil, ranolazine, ivabradine and trimetazidine) may be } \\
\text { considered for first-line treatment according to heart rate, blood pressure and } \\
\text { tolerance }\end{array}$} & & \\
\hline \multirow[t]{5}{*}{ Other } & \multicolumn{3}{|c|}{ Short-acting nitrates are recommended for immediate relief of effort angina } & I & $\mathrm{B}$ \\
\hline & \multicolumn{3}{|c|}{$\begin{array}{l}\text { When long-acting nitrates are prescribed, a nitrate-free or low-nitrate interval should } \\
\text { be considered to reduce tolerance }\end{array}$} & IIa & $\mathrm{B}$ \\
\hline & \multicolumn{3}{|c|}{$\begin{array}{l}\text { In patients with a low heart rate and blood pressure, ranolazine or trimetazidine may } \\
\text { be considered as first-line to reduce angina frequency and improve exercise tolerance }\end{array}$} & IIb & $\mathrm{C}$ \\
\hline & \multicolumn{3}{|c|}{$\begin{array}{l}\text { In selected patients, the combination of a } \beta \text {-blocker or a calcium channel blocker with } \\
\text { a second-line drug (nicorandil, ranolazine, ivabradine and trimetazidine) may be } \\
\text { considered for first-line treatment according to heart rate, blood pressure and } \\
\text { tolerance }\end{array}$} & IIb & $\mathrm{B}$ \\
\hline & \multicolumn{3}{|c|}{$\begin{array}{l}\text { Nitrates are not recommended in patients with hypertrophic obstructive } \\
\text { cardiomyopathy or co-administration with phosphodiesterase inhibitors }\end{array}$} & III & $\mathrm{B}$ \\
\hline AHA recommendat & tions & Treatment option & & lass & Level \\
\hline \multirow[t]{2}{*}{ First line } & & $\beta$-blocker & I & & $\mathrm{B}$ \\
\hline & & $\begin{array}{l}\text { Long-acting non-dihydropyridine calcium channel blocker } \\
\text { (e.g. verapamil or diltiazem) }\end{array}$ & II & & $\mathrm{B}$ \\
\hline \multirow[t]{4}{*}{ Second line } & & $\begin{array}{l}\text { Calcium channel blocker/long-acting nitrates when } \beta \text {-blockers } \\
\text { contraindicated } \\
\text { or unacceptable side effects }\end{array}$ & I & & $\mathrm{B}$ \\
\hline & & $\begin{array}{l}\text { Addition of calcium channel blocker/long-acting nitrates if } \beta \text {-blocker } \\
\text { unsuccessful alone }\end{array}$ & I & & $\mathrm{B}$ \\
\hline & & $\begin{array}{l}\text { Ranolazine can be used as a substitute if initial treatment } \\
\text { with a } \beta \text {-blocker is } \\
\text { ineffective, contraindicated or not tolerated }\end{array}$ & II & & $\mathrm{B}$ \\
\hline & & Addition of ranolazine if initial treatment with $\beta$-blocker unsuccessful & II & & A \\
\hline Other & & Sublingual nitroglycerin for immediate relief of angina & I & & $\mathrm{B}$ \\
\hline
\end{tabular}


the composite primary endpoint of cardiovascular death or non-fatal myocardial infarction [35]. Similarly, the BEAUTIFUL trial of ivabradine in patients with CAD and left ventricular systolic dysfunction did not demonstrate improvements in the primary composite endpoint of cardiovascular death, hospitalisation for acute MI, or hospitalisation for new or worsening heart failure [36]. A Cochrane Review of ranolazine similarly did not find any reduction in cardiovascular death [37]. However, ranolazine significantly reduced glycated haemoglobin levels $\left(\mathrm{HbA}_{1 \mathrm{c}}\right)$ in patients with stable angina enrolled in the MERLIN trial, thought due to $\beta$-cell preservation, inhibition of glucose secretion and enhanced insulin secretion [38].

\section{Should Long-Acting Nitrates be the First Choice Second-Line Agent?}

Long-acting nitrates are the most commonly prescribed class of anti-anginal worldwide and their utilisation in the Middle East and Gulf Region is high. They are metabolised to produce vasoactive nitric oxide and, at low doses, venodilate to reduce preload, venous return, ventricular volume and myocardial tension leading to reduced myocardial oxygen demand. At higher doses, they vasodilate coronary arteries, improve subendocardial perfusion, decrease ventricular diastolic pressure and lower blood pressure. Short-acting nitrates have a Class I Level B recommendation for the immediate relief of angina in the 2019 ESC guidelines. Long-acting nitrates have been upgraded and are now recommended if $\beta$-blocker or calcium channel blocker therapy is unsuccessful. However, while they are frequently prescribed, their use is not supported by a high-quality evidence base with no new supporting evidence that they provide significant added anti-anginal effects on top of first-line drugs $[28,29]$. In metaanalyses, long-acting nitrates are not superior to other anti-anginals at improving symptoms and exercise outcomes [39-41]. Other studies have suggested that long-acting nitrates cause endothelial dysfunction from mechanisms such as the production of reactive oxygen species
$[42,43]$. Furthermore, nitrate tolerance also remains a significant real-world problem. Extended-release nitrates should be dosed with a nitrate-free interval of at least $8 \mathrm{~h}$. In patients who develop nitrate tolerance, there have been increasing concerns regarding adverse cardiovascular outcomes with the long-term use of nitrates due to the accumulation of free radicals, increased vasoconstriction and rebound angina [43-46]. Pseudo-tolerance may also develop, which is thought to be due to counterregulatory responses from activation of the renin-angiotensin-aldosterone system, increased circulating catecholamines and vasopressin, sodium retention and expansion of plasma volume [47].

In registry data, long-term nitrate therapy (18 months) in patients with healed myocardial infarction was associated with increased recurrent coronary events [48]. The Japanese Coronary Artery Disease (JCAD) Study of patients who had significant stenosis in at least one coronary artery, and who were followed-up for an average of 2.7 years, found that nitrates had an approximately $15 \%$ increase in adverse outcomes $(p=0.005)$. In vasospastic angina, there is an indication of increased risk of major adverse cardiac events in those on long-term nitrates and when combined with nicorandil [49-51].

\section{Nicorandil}

Nicorandil may be a useful option especially if considering a nitric oxide donor for treatment of symptomatic angina. It may be particularly helpful in the Middle East given the high prevalence of DM and its association with coronary microvascular dysfunction [52], a condition in which nicorandil has shown benefit $[53,54]$. In addition to its vasodilatory effects, it is also cardioprotective and has properties that mimic ischaemic preconditioning (Fig. 1). Furthermore, it does not induce endothelial dysfunction or significant tolerance, and can mediate vasodilatation at a microcirculatory level. It has favourable characteristics compared to long-acting nitrates and other nitric oxide donors such as molsidomine [55] 


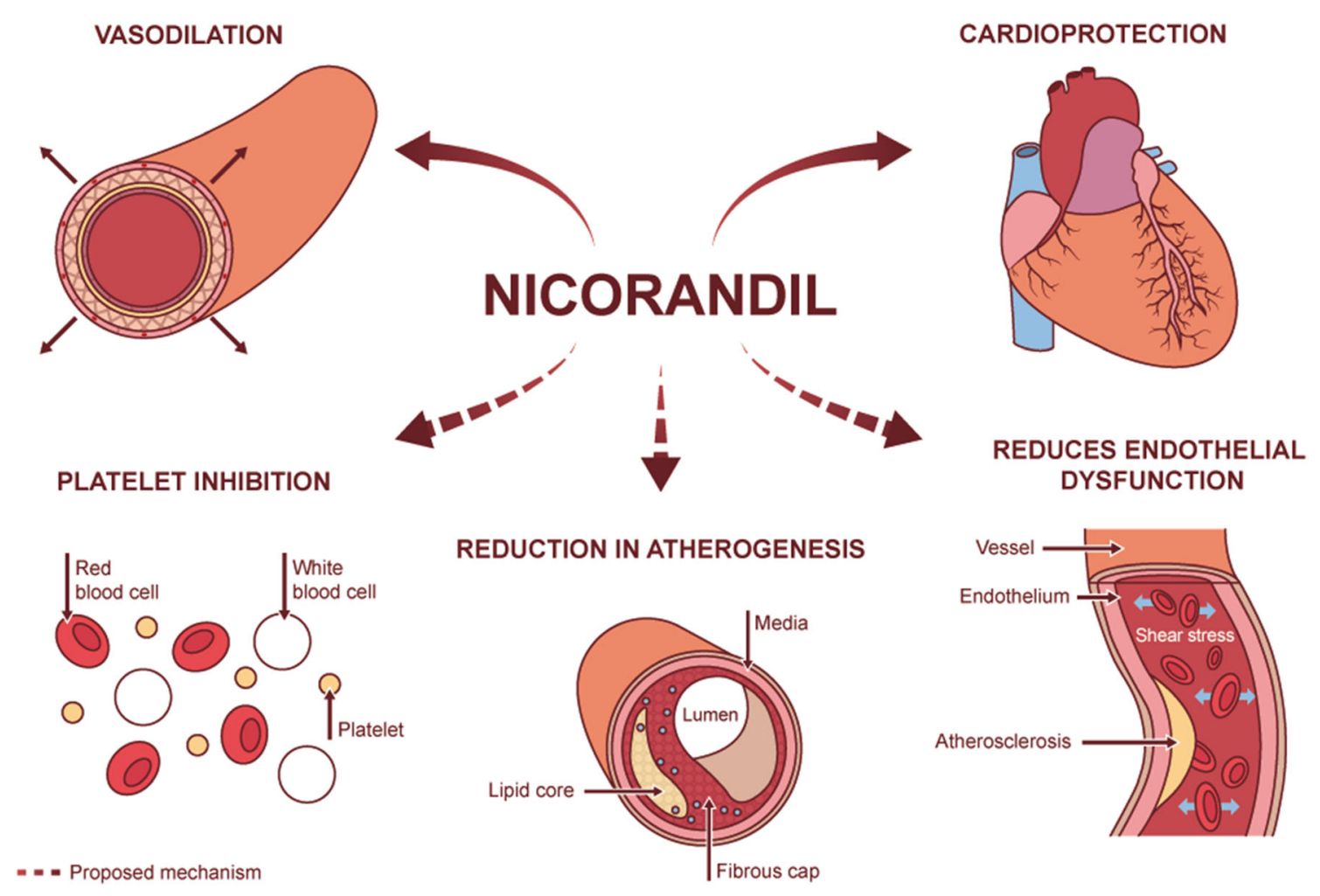

Fig. 1 Pharmacodynamic effects of nicorandil

(see Table 2). In the following sections, we review the pharmacological and clinical profile of nicorandil and place its role in the context of current angina management.

\section{Pharmacology and Physiology}

Nicorandil ( $\mathrm{N}$-[2-(Nitro-oxy) ethyl]-3 pyridine carboxamide) is a nitrate derivative of nicotinamide that has a dual mechanism of action where it acts as an adenosine-sensitive potassium-channel $\left(\mathrm{K}^{+\mathrm{ATP}}\right)$ opener as well as a nitric oxide donor (Fig. 2). Via nitric oxide-mediated signalling pathways in vascular smooth muscle cells, it acts as a balanced coronary and peripheral vasodilator reducing both preload and afterload as well as improving coronary blood flow [56-58]. Therefore, it affects several of the main haemodynamic determinants of oxygen demand without affecting myocardial conduction or contractility [59]. Early studies in the late 1980s investigated the physiology, efficacy, dose response and duration of action of nicorandil. After administration of $20 \mathrm{mg}$ or $40 \mathrm{mg}$ of nicorandil, coronary diameter was measured in the major epicardial arteries of patients undergoing cardiac catheterisation for suspected CAD [60]. Increases in mean diameter were demonstrated in the proximal, midpoint and distal segments, as well as in stenotic segments. Myocardial oxygen consumption also decreased $14 \%$ and $22 \%$ at doses of $20 \mathrm{mg}$ and $40 \mathrm{mg}$, respectively. Nicorandil dilates the coronary arteries without producing coronary steal, exacerbation of myocardial ischaemia or abrupt withdrawal syndrome [61].

In cardiac mitochondria, nicorandil activates potassium-ATP channels $\left(\mathrm{K}^{+}{ }_{\text {ATP }}\right)$ whose downstream pathways are cytoprotective, thus mimicking ischaemic preconditioning (Fig. 2) $[62,63]$. Although the precise mechanism by which this occurs is unknown, several theories have been proposed. By activating sarcolemmal $\mathrm{K}^{+}{ }_{\text {ATP }}$ channels, nicorandil is thought to stabilise the resting membrane potential and markedly shorten the duration of the action potential, reducing calcium overload and 
Table 2 Comparison of nitrates, nicorandil and molsidomine

\begin{tabular}{|c|c|c|c|}
\hline & Long-acting nitrates & Nicorandil & Molsidomine \\
\hline $\begin{array}{l}\text { Evidence for benefit in } \\
\text { stable angina }\end{array}$ & Yes & Yes & Yes [102-104] \\
\hline Randomised evidence & Yes $[105]$ & Yes & Yes [104] \\
\hline $\begin{array}{l}\text { Comparison against } \\
\text { placebo }\end{array}$ & Yes $[105]$ & Yes & Yes [104] \\
\hline $\begin{array}{l}\text { Benefit as add-on to } \\
\text { first line therapy }\end{array}$ & $\begin{array}{l}\text { Yes, although poor-quality evidence } \\
\text { [37] }\end{array}$ & Yes & Yes \\
\hline $\begin{array}{l}\text { Benefit in } \\
\text { microvascular } \\
\text { dysfunction }\end{array}$ & No $[106,107]$ & Yes, but limited evidence & No evidence \\
\hline $\begin{array}{l}\text { Concerns about } \\
\text { tolerance and } \\
\text { endothelial } \\
\text { dysfunction }\end{array}$ & Yes & No & $\begin{array}{l}\text { Evidence unclear } \\
\quad[102,108]\end{array}$ \\
\hline \multirow[t]{4}{*}{$\begin{array}{l}\text { Cost for } 28 \text { days } \\
\text { treatment [109] }\end{array}$} & $\begin{array}{l}\text { Isosorbide mononitrate } 25 \mathrm{mg} \\
\text { modified-release capsules; } \\
\text { NHS prescription price: } £ 9\end{array}$ & $\begin{array}{l}\text { Nicorandil ( } 20 \text { mg twice a } \\
\text { day); NHS prescription } \\
\text { price: } £ 9\end{array}$ & $\begin{array}{l}\text { Molsidomine tablets } \\
(2 \mathrm{mg}) \text {; NHS } \\
\text { prescription price: } \\
£ 9.00\end{array}$ \\
\hline & $\begin{array}{l}\text { Isosorbide mononitrate MR tablets } \\
(60 \mathrm{mg}) \text {; Basic NHS price: } £ 10.50\end{array}$ & $\begin{array}{l}\text { Nicorandil ( } 20 \mathrm{mg} \text { twice a } \\
\text { day); Basic NHS price: } \\
£ 4.59\end{array}$ & \\
\hline & $\begin{array}{l}\text { Isosorbide dinitrate ( } 20 \mathrm{mg} \text { four times a } \\
\text { day): } £ 29.04\end{array}$ & $\begin{array}{l}\text { Nicorandil ( } 10 \mathrm{mg} ; 30 \\
\text { tablets): } 30 \text { Saudi Riyal }\end{array}$ & \\
\hline & $\begin{array}{l}\text { Isosorbide dinitrate (10 mg; } 30 \text { tablets): } \\
25 \text { Saudi Riyal; ( } 20 \mathrm{mg} ; 30 \text { tablets): } \\
45 \text { Saudi Riyal }\end{array}$ & $\begin{array}{l}\text { Nicorandil ( } 20 \mathrm{mg} ; 30 \\
\text { tablets): } 60 \text { Saudi Riyal }\end{array}$ & \\
\hline
\end{tabular}

cellular energy demands [64, 65]. Increasing evidence, however, has suggested the involvement of other mechanisms. Nicorandil opens the mitochondrial $\mathrm{K}^{+}$ATP channel, which is thought to inhibit activation of the mitochondrial permeability transition pore, a protein in the mitochondrial inner membrane that forms in conditions of stress to allow cell death [63, 66, 67]. Nicorandil has also been implicated in suppressing other apoptotic pathways (such as the endoplasmic PI3K/Akt pathway in a model of myocardial ischaemia reperfusion injury) and in activating others (e.g. Nrf2/HO-1 signalling pathway in a model of coronary microembolisation) to prevent cell death $[68,69]$.

In patients with stable angina, intravenous nicorandil was able to induce a pre-conditioning effect compared to control (intravenous isosorbide dinitrate) as measured by ST segment change on balloon inflation during percutaneous transluminal coronary angioplasty [62]. Other effects of nicorandil have been proposed, such as reduced atherosclerosis and plaque necrosis [70], anti-platelet properties and protection against long-term endothelial 


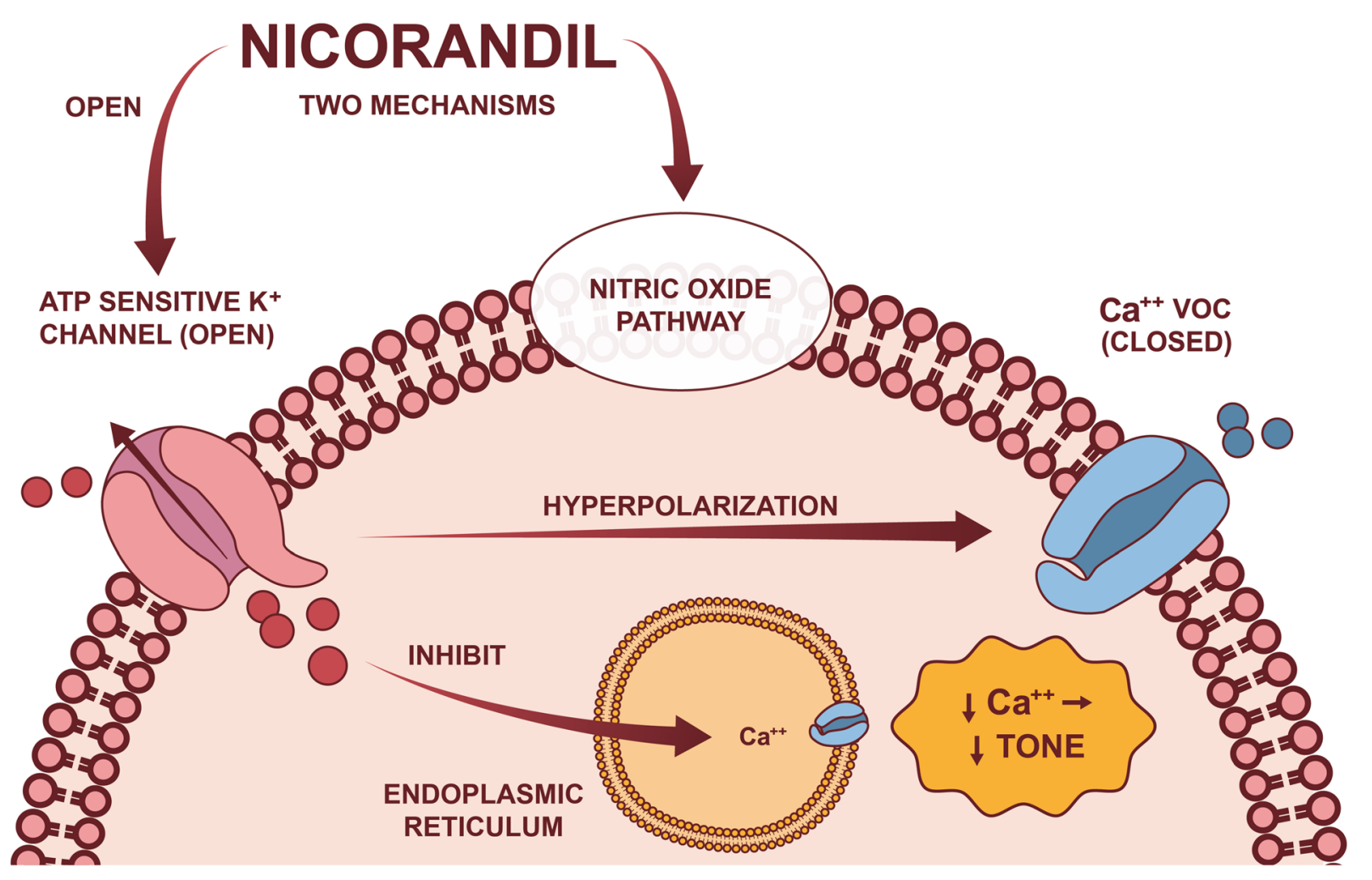

Fig. 2 Mechanism of action of nicorandil

dysfunction (Fig. 1) [71, 72]. However, such data are preliminary.

\section{PHARMACOKINETICS AND DOSAGE}

Nicorandil has good oral bioavailability (> 75\%) with rapid and almost complete absorption via the gastrointestinal tract. It is not significantly metabolised by the liver, avoiding first-pass metabolism, and has a linear dose-to-plasma concentration, reaching peak plasma concentration after 30-60 min and a steady state after approximately 96-120 h (4-5 days) (Table 3) $[41,73,74]$. During repeated dosing of nicorandil $20 \mathrm{mg}$ twice a day, steady-state plasma concentrations of $\sim 250-300 \mu \mathrm{m} / \mathrm{L}$ occur within 4 days of the first dose [65]. Food delays the absorption rate of nicorandil but has a minimal effect on bioavailability or peak plasma concentration.
Nicorandil is extensively metabolised, undergoing denitration and then metabolism along the nicotinamide/nicotinic acid pathway. It is almost fully eliminated via the kidney $(<2 \%$ of dose excreted via biliary tract $)$ with more than $60 \%$ of the administered dose eliminated in the urine $24 \mathrm{~h}$ after dosing. It is eliminated as the denitrated compound (2nicotinamidoethanol) and its derivates (nicotinuric acid, nicotinamide, $N$-methylnicotinamide and nicotinic acid). Only $1 \%$ of nicorandil is excreted unchanged in the urine. It has a half-life of $1-2 \mathrm{~h}$ for the main phase of elimination and is almost entirely eliminated from plasma within $8 \mathrm{~h}$. Most nicorandil metabolites are excreted within 1 day of dosing, while some are excreted more slowly as nicotinamide derivatives. Pharmacokinetics are not significantly different in the elderly or those with chronic renal or hepatic impairment $[74,75]$.

Nicorandil is recommended to be prescribed as a twice daily regimen as its clinical effects, including improvements in time to angina or 


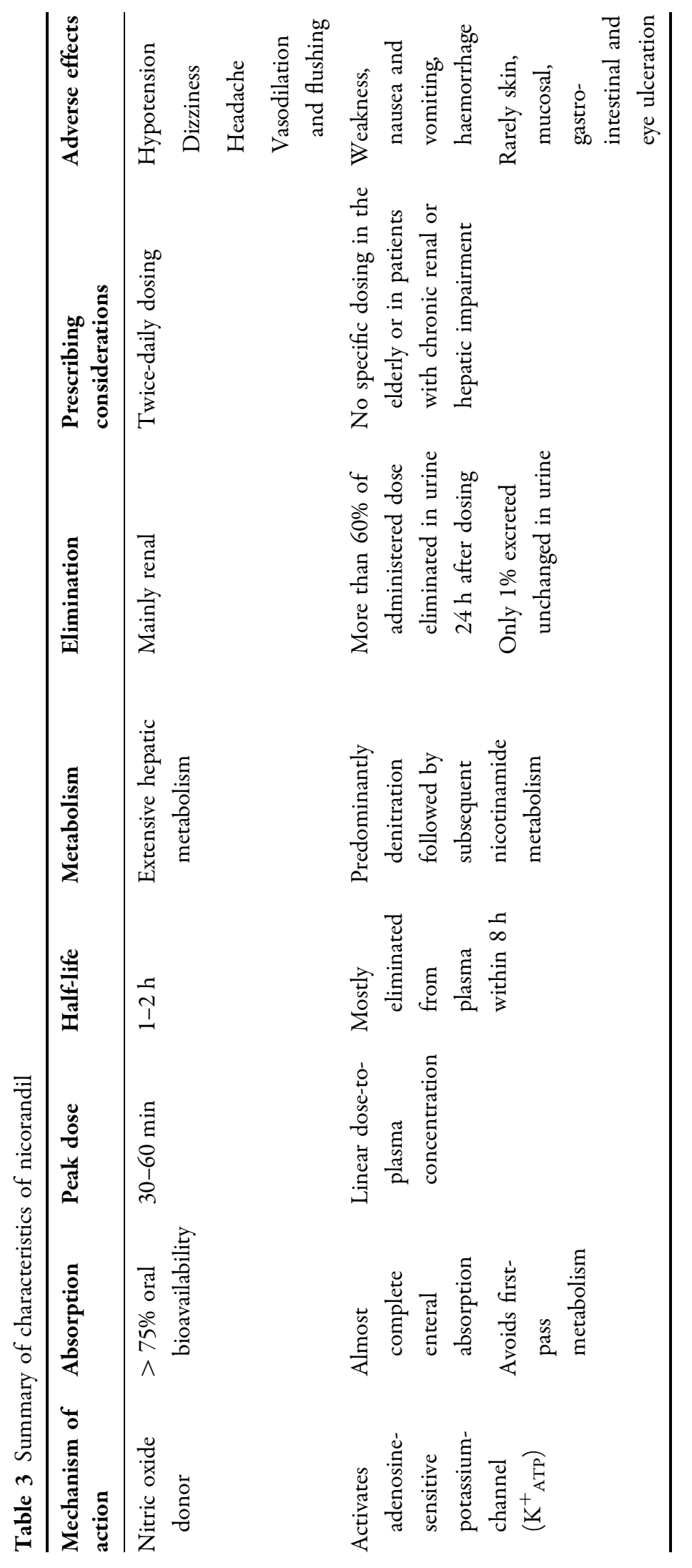


$1 \mathrm{~mm}$ ST depression, persists for $\sim 12 \mathrm{~h} \mathrm{[76].}$ Approved dosages may vary between countries. In the UK, the British National Formulary advises that nicorandil should be initiated at 5-10 mg twice daily, then increased if tolerated to $40 \mathrm{mg}$ twice daily [77]. A usual dose of 10-20 mg twice daily, to which most patients respond, is recommended. For patients susceptible to headaches, a lower initial dose should be used. Dose reduction in the elderly is not required. Nicorandil is not licenced by the Food and Drug Administration for use in the US.

\section{CLINICAL EFFICACY}

Several small placebo-controlled studies in the late 1980s first demonstrated clinical efficacy with nicorandil [78-81]. At doses of $20 \mathrm{mg}$, $40 \mathrm{mg}$ and $60 \mathrm{mg}$, time to onset of angina on treadmill improved by 58, 96 and $125 \mathrm{~s}$ over baseline $(p<0.01)$, with improvements in exercise capacity maintained at $6 \mathrm{~h}$ compared to placebo [80]. Plasma concentrations of nicorandil correlated with reductions in blood pressure at $2 \mathrm{~h}$ after administration. Dosedependent effects on blood pressure were noted ( 2 of 6 patients experienced severe dizziness at $60 \mathrm{mg}$ dose), while adverse events were doserelated. Other studies have shown nicorandil to have equivalent anti-anginal effects to longterm nitrates [82-86], $\beta$-blockers [87-90] and calcium channel blockers [91-94] in terms of time to angina, exercise duration and time to $1 \mathrm{~mm}$ segment depression (Table 4) [65].

In 2002, the landmark Impact of Nicorandil in Angina (IONA) RCT was reported, and it remains the sole large-scale RCT of nicorandil to date [32]. This study sought to investigate the effect of nicorandil compared with placebo on the frequency of adverse coronary events in patients with stable angina pectoris secondary to epicardial CAD. The investigators recruited 5126 patients who were randomised to receive either $20 \mathrm{mg}$ nicorandil twice a day $(n=2565)$, initially $10 \mathrm{mg}$ twice a day and then increased to $20 \mathrm{mg}$ after 2 weeks, or placebo $(n=2561)$ on top of standard anti-anginal treatment. Those in the nicorandil group had concomitant use of anti-anginals as follows: $\beta$-blockers $57 \%$, calcium-channel blockers 55\%, and nitrates $87 \%$. For secondary prevention, $56 \%$ also took statins, $89 \%$ aspirin/antiplatelets, and 29\% angiotensin-converting enzyme inhibitors. A significant improvement in the primary composite endpoint (coronary heart disease death, non-fatal myocardial infarction, or unplanned hospital admission for cardiac chest pain) was shown [398 (15.5\%) events in the placebo group vs. $337(13.1 \%)$ in the nicorandil group (hazard ratio $0.83,95 \%$ CI $0.72-0.97 ; p=0.014)]$ (Fig. 3). Cardiovascular mortality and myocardial infarction were not significantly different, with the benefit mainly due to a reduction in unplanned hospitalisation for unstable angina. Although there was no significant difference in the rate of the secondary endpoint (coronary heart disease death or non-fatal myocardial infarction), nicorandil reduced the rate of ACS (hazard ratio $0.79 ; p=0.028$ ) and of all cardiovascular events (hazard ratio $0.86 ; p=0.027$ ). All-cause mortality was no different. The majority of patients were established on concomitant nitrate therapy ( $87 \%$ in both nicorandil and placebo groups) suggesting that the observed beneficial effect may have been mediated through the action of nicorandil on mitochondrial potassium-ATP channels [95]. Subgroup analyses confirmed the benefit was observed across a range of cardiovascular risk factors, baseline anti-anginal medications, and in those with the highest risk of recurrent events $[96,97]$.

In 2010, the JCAD study, a multi-centre prospective observational study $(n=2558)$, investigating cardiovascular outcomes in patients with stable angina, reported that nicorandil improved all-cause mortality by 35\% $(p=0.0008)$ compared to a propensity scorematched control population [92]. There was a consistent and significant reduction in the main secondary endpoints in patients treated with nicorandil, in particular cardiac death (56\%), fatal myocardial infarction (56\%), cerebral or vascular death $(71 \%)$ and congestive cardiac failure (33\%). A meta-analysis of 17 RCTs found that the addition of nicorandil significantly reduced cardiovascular events, but there were no significant differences in all-cause mortality or repeat revascularisation [98]. The prevention 
Table 4 Studies on the clinical efficacy of nicorandil in angina

\begin{tabular}{|c|c|c|c|c|}
\hline $\begin{array}{l}\text { Author and } \\
\text { date }\end{array}$ & $\begin{array}{l}\text { Study size and } \\
\text { treatment duration }\end{array}$ & Study design & Dosing and comparator & Outcome \\
\hline \multicolumn{5}{|c|}{ Nicorandil vs. placebo } \\
\hline $\begin{array}{l}\text { IONA study } \\
\text { group } 2002 \\
\text { [95] }\end{array}$ & $\begin{array}{l}n=5126 \\
\text { Median } \\
1.6 \text { years } \pm 0.5\end{array}$ & $\begin{array}{l}\text { Multicentre } \\
\text { placebo- } \\
\text { controlled } \\
\text { RCT }\end{array}$ & $\begin{array}{l}20 \text { mg nicorandil twice } \\
\text { daily vs. placebo }\end{array}$ & $\begin{array}{l}\text { Significant improvement in } \\
\text { reduction in major } \\
\text { coronary events: } 15.5 \% \text { vs. } \\
13.1 \% \text { (hazard ratio } 0.83 \text {, } \\
95 \% \text { CI } 0.72-0.91, \\
p=0.068 \text { ) of primary } \\
\text { composite endpoint } \\
\text { (coronary heart disease } \\
\text { death, non-fatal } \\
\text { myocardial infarction, } \\
\text { unplanned hospitalisation } \\
\text { for angina) }\end{array}$ \\
\hline \multicolumn{5}{|c|}{ Comparison with long-acting nitrates } \\
\hline $\begin{array}{l}\text { Döring et al. } \\
1992[83]\end{array}$ & $\begin{array}{l}n=129 \\
4-6 \text { weeks }\end{array}$ & $\begin{array}{l}\text { Multicentre } \\
\text { RCT } \\
\text { Two double- } \\
\text { blind studies: } \\
\text { 1. Comparison } \\
\text { with isosorbide } \\
\text { mononitrate in } \\
\text { crossover } \\
\text { design } \\
\text { 2. Nicorandil } \\
\text { and isosorbide } \\
\text { dinitrate } \\
\text { administered } \\
\text { to two parallel } \\
\text { groups }\end{array}$ & $\begin{array}{l}\text { 1. } 20 \mathrm{mg} \text { nicorandil vs. } \\
20 \mathrm{mg} \text { mononitrate twice } \\
\text { daily } \\
\text { 2. } 10 \mathrm{mg} \text { three times a day } \\
\text { for } 2 \text { weeks, then } 20 \mathrm{mg} \\
\text { three times a day for } \\
4 \text { weeks }\end{array}$ & $\begin{array}{l}\text { Equally effective in } \\
\text { treatment of stress- } \\
\text { induced angina } \\
\text { Prolonged bicycle exercise } \\
\text { tolerance, reduced ST- } \\
\text { segment depression and } \\
\text { reduced weekly angina } \\
\text { attack rates } \\
\text { No significant difference } \\
\text { between groups } \\
\text { No development of } \\
\text { tolerance to nitrates }\end{array}$ \\
\hline $\begin{array}{l}\text { Falcone et al. } \\
1993 \text { [85] }\end{array}$ & $n=41$ & $\begin{array}{l}\text { Double-blind } \\
\text { RCT }\end{array}$ & $\begin{array}{l}\text { Nicorandil 10-20 mg twice } \\
\text { daily }\end{array}$ & $\begin{array}{l}\text { Significant increases in time } \\
\text { to angina and maximum } \\
\text { ST depression }\end{array}$ \\
\hline $\begin{array}{l}\text { Ciampricotti } \\
\text { et al. } 2000 \\
\text { [82] }\end{array}$ & $\begin{array}{l}n=194 \\
\text { Elderly } \\
\text { patients } \geq 65 \text { years } \\
\text { with stable angina and } \\
\text { positive exercise test } \\
(\geq 0.1 \mathrm{mV} \mathrm{ST} \text { - } \\
\text { segment depression }) \\
4 \text { weeks }\end{array}$ & $\begin{array}{l}\text { Multicentre, } \\
\text { double-blind, } \\
\text { double- } \\
\text { dummy } \\
\text { controlled }\end{array}$ & $\begin{array}{l}10 \text { mg twice daily } \\
\text { nicorandil ISMN }\end{array}$ & $\begin{array}{l}\text { Significant postponement } \\
\text { of onset of ischaemia } \\
\text { compared with baseline } \\
\text { No differences between } \\
\text { nicorandil and ISMN }\end{array}$ \\
\hline
\end{tabular}


Table 4 continued

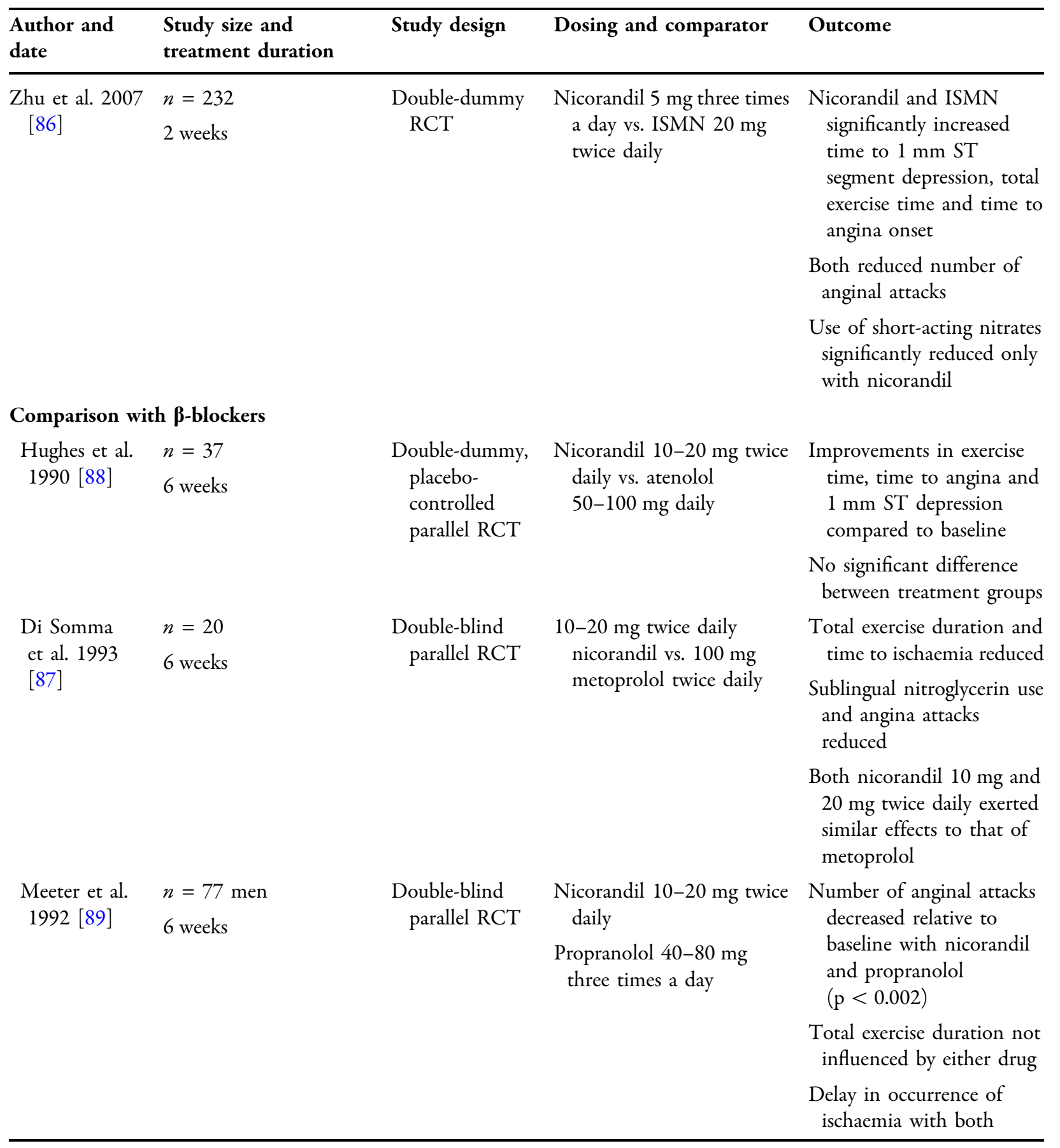


Table 4 continued

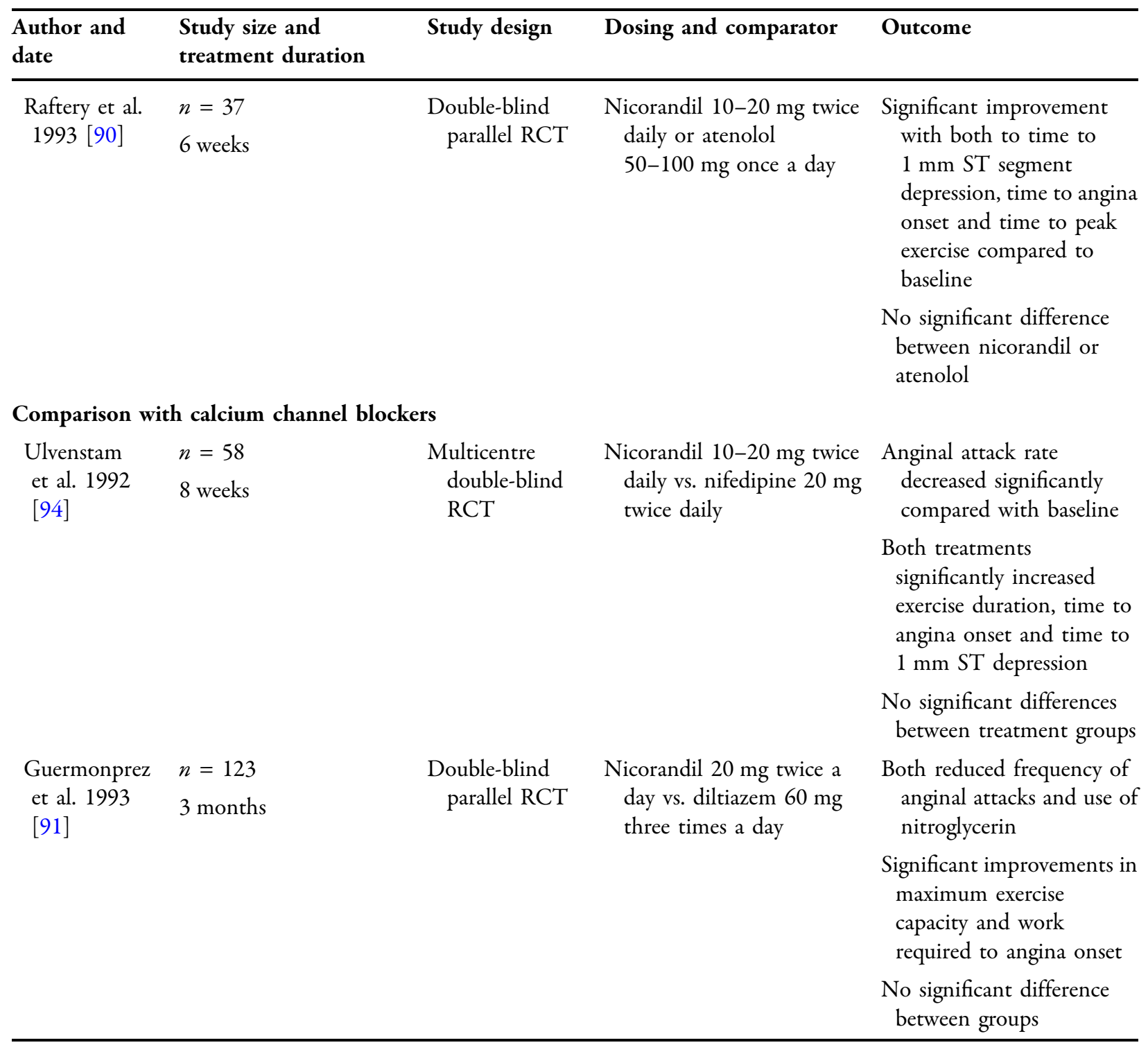


Table 4 continued

\begin{tabular}{llcc}
\hline $\begin{array}{l}\text { Author and } \\
\text { date }\end{array}$ & $\begin{array}{l}\text { Study size and } \\
\text { treatment duration }\end{array}$ & Study design & Dosing and comparator \\
\hline $\begin{array}{l}\text { Swan Study } \\
\text { Group }\end{array}$ & $n=121$ & $\begin{array}{c}\text { Multicentre, } \\
\text { double-blind, }\end{array}$ & $\begin{array}{c}\text { Nicorandil 10-20 mg twice } \\
\text { daily vs. amlodipine }\end{array}$ \\
$\begin{array}{l}\text { (Chatterjee } \\
\text { et al.) } 1999\end{array}$ & RCT & $5-10$ mg daily \\
[93] & & & \\
\end{tabular}

Outcome

Time to onset of STsegment depression increased only with amlodipine

Time to onset of angina and total exercise duration increased with both

Both reduced magnitude of ST depression at maximal workload, weekly angina attacks and nitroglycerin use

No differences between treatment groups

\section{Comparison with standard anti-anginal therapy}

Jiang et al. $\quad n=402$

2016 [99] 12 weeks
Multicentre, open-label, RCT
12 weeks of nicorandil ( $5 \mathrm{mg}$ three times daily) plus current standard anti-anginal therapy vs. current standard antianginal therapy
Significantly reduced number of myocardial ischaemic attacks with nicorandil compared to control (adjusted ratio 0.503 ; $95 \% \mathrm{CI}$ 0.301-0.840; $p=0.0086$ )

No significant differences in total myocardial ischaemic burden, maximum STdepression, longest duration of STdepression, 6-min walk test or heart rate variability

$11.7 \%(n=23)$ of nicorandil group and $6.3 \%$ $(n=13)$ of control group reported at least treatment adverse event 


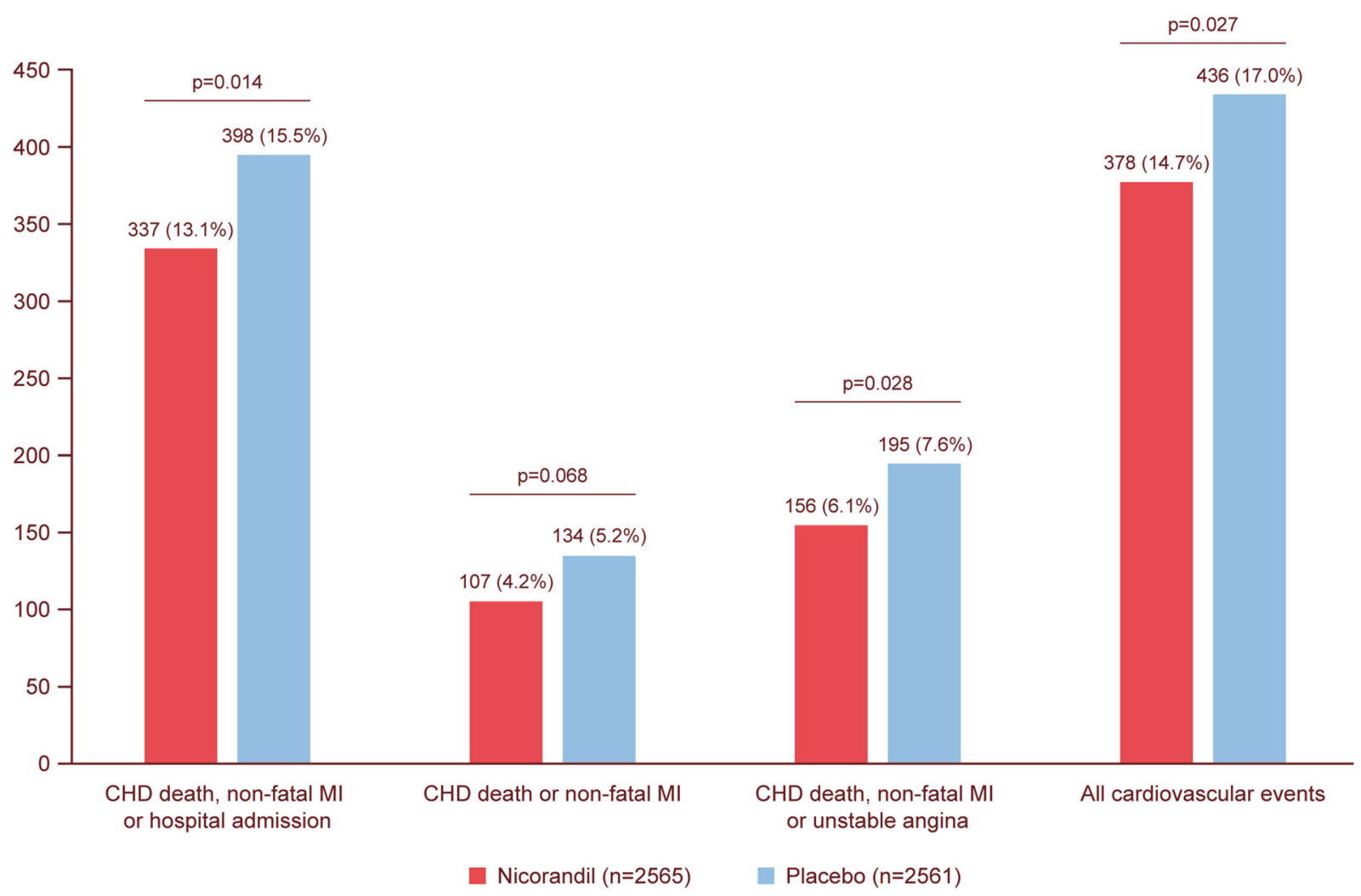

Fig. 3 Major clinical outcomes in the Impact Of Nicorandil in Angina (IONA) trial [32]

of recurrent adverse cardiovascular events, as reported in the literature for nicorandil, remains a major goal of treatment, and has not been demonstrated for other anti-anginal drugs.

Recently, an open label RCT by Jiang et al. $(n=402)$ evaluated nicorandil in the context of contemporary anti-anginal medications. Patients either received nicorandil $5 \mathrm{mg}$ three times a day for 12 weeks in addition to standard anti-anginal therapy, or continued on their current prescribed anti-anginals. Add-on nicorandil therapy was associated with a lower number of ischaemic episodes on $24 \mathrm{~h}$ Holter monitoring, but no significant differences were found in total ischaemic burden, maximum STdepression, longest duration of ST-depression, 6-min walk test or heart rate variability [99]. Additional adequately-powered RCTs comparing nicorandil against contemporary, maximally tolerated anti-anginal drugs will be needed to further support these results.

Finally, nicorandil has been shown to be effective and is currently recommended in guidelines for the management of vasospastic angina [100, 101]. Nicorandil may also, theoretically, be beneficial in patients with angina secondary to coronary microvascular dysfunction or microvascular spasm, although the evidence base in support of this is limited [102]. Intracoronary administration of nicorandil has been shown to dilate the coronary microcirculation and to decrease microcirculatory resistance in patients having undergone percutaneous coronary intervention (PCI) for stable angina or ST-elevation myocardial infarction [53, 103]. In a small double-blind placebo-controlled crossover RCT of patients with microvascular angina $(n=13)$, a 2 -week course of oral nicorandil significantly improved time to $1 \mathrm{~mm}$ ST depression $(p=0.026)$ and total exercise duration $(p=0.036)$ compared with placebo [102]. Although a meta-analysis of RCTs of nicorandil in non-obstructive CAD suggested that it did not improve coronary flow reserve, nicorandil was shown to reduce the index of microcirculatory resistance 
significantly compared to controls $(p=0.0004)$ [54]. Conversely, nitrates have been shown not to be efficacious in patients with microvascular angina. A study of 53 patients demonstrated that short-acting sublingual isosorbide dinitrate improved results on exercise stress tests for patients with obstructive CAD but not for microvascular angina [104]. Although a recent meta-analysis of RCTs of the effects of nicorandil in patients with unobstructed coronary arteries (24 RCTs; $n=2323$ ) suggested that nicorandil may improve anginal symptoms, time to $1 \mathrm{~mm}$ ST-segment depression on treadmill, and endothelial dysfunction, the strength of evidence is low and insufficient to draw firm conclusions [105]. The available data support the hypothesis that nicorandil is a plausible drug for treating coronary microvascular dysfunction and vasospasm at both the epicardial and microvascular level. Further studies investigating nicorandil for these indications would be extremely valuable, as the current treatment options for such patients, who can be extremely debilitated by symptoms, is very limited.

\section{FUTURE DIRECTIONS}

A significant proportion of patients experience a recurrence of their angina after successful revascularisation. The management of recurrent or persistent angina after revascularisation remains an unmet need. These symptoms may be explained by the presence of persistent ischaemia secondary to coronary microvascular dysfunction [106, 107]. Coronary microvascular dysfunction is thought to play a significant role in the pathophysiology of recurrent angina after PCI. Of note, recent RCTs of ranolazine and trimetazidine in an unselected population of patients undergoing PCI failed to achieve their primary endpoints [108, 109]. However, these studies did not specifically evaluate patients with persistent ischaemia and evidence of coronary microvascular dysfunction. Nicorandil (intravenous or intracoronary) at the time of PCI has been shown to reduce microvascular dysfunction induced by coronary stenting and is suggested to improve cardiovascular outcomes [53, 103, 110, 111]. However, the long-term use of oral nicorandil to treat residual ischaemia and persistent or recurrent angina in patients with coronary microvascular dysfunction after revascularisation has not been investigated and would appear a fruitful avenue for future investigation.

In addition, given the large and growing burden of DM in the Middle East and Gulf region, the incidence of diffuse small vessel disease and coronary microvascular dysfunction is only expected to rise [112]. Data from the IONA study is limited in this regard, only $\sim 8 \%$ of participants had DM and subgroup analysis did not demonstrate any interaction between the benefit observed with nicorandil and DM status [113]. With further adequately-powered studies of its effect on cardiovascular outcomes in patients with stable angina pectoris secondary to coronary microvascular dysfunction, nicorandil may prove to be a plausible drug choice in this population.

\section{SIDE EFFECTS AND CONTRA- INDICATIONS}

Side effects of nicorandil include headache, flushing, dizziness, hypotension and, rarely, ulceration, which may be oral, ocular, peri-anal or gastrointestinal. The use of aspirin, nonsteroidal anti-inflammatory drugs, or corticosteroids with nicorandil increases the risk of gastrointestinal ulceration, perforations, or haemorrhage, while patients with diverticular disease may be at risk of fistula formation or bowel perforation [56]. In patients who develop serious skin, mucosal and eye ulceration, including gastrointestinal ulcers which may progress to perforation, haemorrhage, fistula or abscess, treatment should be stopped and an alternative considered. The most common side effect of headache, occurring in 30\% of patients, can be minimised by starting at a low dose. Importantly, compared to long-acting nitrates, long-term use of nicorandil does not cause significant drug tolerance, endothelial dysfunction or rebound angina [77]. Early animal and clinical studies have demonstrated a lack of development of tolerance; however cross-tolerance with nitroglycerin has been 
suggested and one study observed an attenuation of the time-to- $1 \mathrm{~mm}$ ST segment depression on exercise testing after 2 weeks of treatment with nicorandil [76, 114-116].

Nicorandil is contraindicated in hypotension, left ventricular failure and cardiogenic shock and, as with nitrates, it should not be used with soluble guanylate cyclase stimulators or phosphodiesterase-5 inhibitors due to the risk of severe hypotension. In patients who develop persistent aphthous or severe mouth ulcers, alternative anti-anginals should be considered. In addition, although the combination of nicorandil and long-acting nitrates has not been specifically investigated, it may be safe and able to offer additional clinical benefits. For example, in the IONA study, $87 \%$ of patients in both the nicorandil and placebo groups were reported to have received concomitant nitrates, although there is no specification as to whether these were short- or long-acting [32]. Other studies which have used nicorandil together with long-acting nitrates have not reported significant adverse effects and patients with complex CAD not suitable for revascularisation, or who have refractory angina, may benefit from nicorandil in combination with longacting nitrate therapy [117-120]. Further largescale studies are needed not only to assess their combination but to allow for head-to-head comparison of efficacy and side effects.

\section{CONCLUSION}

Stable symptomatic angina pectoris is a growing population of patients, particularly in the Gulf region, where the prevalence is set to significantly increase in the near future. Given the high and increasing prevalence of obesity, DM and the growing number of patients undergoing revascularisation in the Middle East and Gulf region, coronary microvascular dysfunction is likely a very common mechanism of ischaemia in CCS patients with symptomatic angina in this region. Many of these patients remain symptomatic despite treatment with long-acting nitrates which are very commonly prescribed in the Middle East and Gulf region, the reasons for which have been discussed in this review. Region-specific data on the benefit of pharmacologic treatments, including nicorandil in CCS patients who remain symptomatic with angina, are lacking and muchneeded, particularly noting that optimal medical therapy remains the cornerstone of management in this patient group. This article is based on previously conducted studies and does not contain any studies with human participants or animals performed by any of the authors.

\section{ACKNOWLEDGEMENTS}

Funding. No funding or sponsorship was received by the authors for this work. Merck Serono Middle East FZ Ltd supported the journal's rapid service fee.

Authorship. All named authors meet the International Committee of Medical Journal Editors (ICMJE) criteria for authorship for this article, take responsibility for the integrity of the work as a whole, and have given their approval for this version to be published.

Author Contributions. Dr Kevin Cheng carried out a literature search and extraction of data from studies as well as drafted the manuscript, implemented revisions and designed figures and tables. Dr Khaldoon Alhumood commented and approved drafts, performed local data collection and provided insights as well as designed figures and approved the final draft. Dr Fayez El Shaer revised the manuscript, added comments, and provided epidemiological data review from the Gulf Region as well as approved the final draft. Dr Ranil de Silva participated in the writing of manuscript, critical review of all versions and finalisation of submitted version.

Medical Writing and/or Editorial Assistance. Editorial support was provided by Springer Healthcare Ltd, UK, and was funded by Merck Serono Middle East FZ Ltd. in accordance with Good Publication Practice (GPP3) guidelines (http://www.ismpp.org/gpp3). 
Disclosures. Kevin Cheng, Khaldoon Alhumood, Fayez El Shaer and Ranil De Silva have nothing to disclose.

Compliance With Ethics Guidelines. This article is based on previously conducted studies and does not contain any studies with human participants or animals performed by any of the authors.

Data Availability. Data sharing is not applicable to this article as no datasets were generated or analysed during the current study.

Open Access. This article is licensed under a Creative Commons Attribution-NonCommercial 4.0 International License, which permits any non-commercial use, sharing, adaptation, distribution and reproduction in any medium or format, as long as you give appropriate credit to the original author(s) and the source, provide a link to the Creative Commons licence, and indicate if changes were made. The images or other third party material in this article are included in the article's Creative Commons licence, unless indicated otherwise in a credit line to the material. If material is not included in the article's Creative Commons licence and your intended use is not permitted by statutory regulation or exceeds the permitted use, you will need to obtain permission directly from the copyright holder. To view a copy of this licence, visit http:// creativecommons.org/licenses/by-nc/4.0/.

\section{REFERENCES}

1. Knuuti J, Wijns W, Saraste A, Capodanno D, Barbato E, Funck-Brentano C, et al. 2019 ESC Guidelines for the diagnosis and management of chronic coronary syndromes: The Task Force for the diagnosis and management of chronic coronary syndromes of the European Society of Cardiology (ESC). Eur Heart J. 2019:ehz425.

2. Kligfield P. The early pathophysiolic understanding of angina pectoris (Edward Jenner, Caleb Hillier Parry, Alan Burns). Am J Cardiol. 1982;50(6): 1433-5.
3. World Health Organization. WHO Fact Sheet: Cardiovascular disease (CVDs). https://www.who.int/ news-room/fact-sheets/detail/cardiovasculardiseases-(cvds).

4. Roth GA, Johnson C, Abajobir A, Abd-Allah F, Abera $\mathrm{SF}$, Abyu G, et al. Global, regional, and national burden of cardiovascular diseases for 10 causes, 1990 to 2015. J Am Coll Cardiol. 2017;70(1):1-25.

5. Mendis S, Thygesen K, Kuulasmaa K, Giampaoli S, Mahonen M, Ngu Blackett K, et al. World Health Organization definition of myocardial infarction: 2008-09 revision. Int J Epidemiol. 2011;40(1): $139-46$.

6. Al-Nozha MM, Arafah MR, Al-Mazrou YY, Al-Maatouq MA, Khan NB, Khalil MZ, et al. Coronary artery disease in Saudi Arabia. Saudi Med J. 2004;25(9):1165-71.

7. World Health Organization. Noncommunicable Diseases Country Profiles 2011. Geneva: World Health Organization; 2011. https://www.who.int/ nmh/publications/ncd_profiles2011/en/.

8. Yusuf S, Hawken S, Ounpuu S, Dans T, Avezum A, Lanas F, et al. Effect of potentially modifiable risk factors associated with myocardial infarction in 52 countries (the INTERHEART study): case-control study. Lancet. 2004;364(9438):937-52.

9. Aljefree N, Ahmed F. Prevalence of cardiovascular disease and associated risk factors among adult population in the gulf region: a systematic review. Adv Public Health. 2015:235101.

10. Motlagh B, O’Donnell M, Yusuf S. Prevalence of cardiovascular risk factors in the Middle East: a systematic review. Eur J Cardiovasc Prev Rehabil. 2009;16(3):268-80.

11. World Health Organization. WHO global report on trends in tobacco smoking 2000-2025-first edition. https://www.who.int/tobacco/publicatio ns/surveillance/reportontrendstobaccosmoking/en/ index1.html.

12. Dugani SB, Murad W, Damilig K, Atos J, Mohamed E, Callachan E, et al. Premature myocardial infarction in the Middle East and North Africa: rationale for the Gulf PREVENT Study. Angiology. 2019: 3319719849737.

13. Sorbets E, Fox KM, Elbez Y, Danchin N, Dorian P, Ferrari R, et al. Long-term outcomes of chronic coronary syndrome worldwide: insights from the international CLARIFY registry. Eur Heart J. ehz660.

14. Osman AM, Alsultan MS, Al-Mutairi MA. The burden of ischemic heart disease at a major cardiac 
center in Central Saudi Arabia. Saudi Med J. 2011;32(12):1279-84.

15. Al Slamah T, Nicholl BI, Alslail FY, Melville CA. Selfmanagement of type 2 diabetes in gulf cooperation council countries: a systematic review. PLoS ONE. 2017;12(12):e0189160.

16. International Diabetes Federation. IDF Diabetes Atlas 7th Edition. https://www.idf.org/e-library/ epidemiology-research/diabetes-atlas/13-diabetesatlas-seventh-edition.html.

17. Abuyassin B, Laher I. Diabetes epidemic sweeping the Arab world. World J Diabetes. 2016;7(8):165-74.

18. Al-Rubeaan K, Al-Manaa HA, Khoja TA, Ahmad NA, Al-Sharqawi AH, Siddiqui K, et al. Epidemiology of abnormal glucose metabolism in a country facing its epidemic: SAUDI-DM study. J Diabetes. 2015;7(5):622-32.

19. Omar MS, Khudada K, Safarini S, Mehanna S, Nafach J. DiabCare survey of diabetes management and complications in the Gulf countries. Indian J Endocrinol Metab. 2016;20(2):219-27.

20. Shehab A, Bhagavathula AS, Al-Rasadi K, Alshamsi F, Al Kaab J, Thani KB, et al. Diabetes and mortality in acute coronary syndrome: findings from the Gulf COAST registry. Curr Vasc Pharmacol. 2018.

21. Duarte R, Castela S, Reis RP, Correia MJ, Ramos A, Pereira AP, et al. Acute coronary syndrome in a diabetic population-risk factors and clinical and angiographic characteristics. Rev Port Cardiol. 2003;22(9):1077-88.

22. Herlitz J, Brandrup-Wognsen G, Emanuelsson $H$, Haglid M, Karlson BW, Karlsson T, et al. Mortality and morbidity in diabetic and nondiabetic patients during a 2-year period after coronary artery bypass grafting. Diabetes Care. 1996;19(7):698-703.

23. Peterson PN, Spertus JA, Magid DJ, Masoudi FA, Reid K, Hamman RF, et al. The impact of diabetes on one-year health status outcomes following acute coronary syndromes. BMC Cardiovasc Disord. $2006 ; 6: 41$

24. Ferrari R, Camici PG, Crea F, Danchin N, Fox K, Maggioni AP, et al. A 'diamond' approach to personalized treatment of angina. Nat Rev Cardiol. 2018;15:120-32.

25. Sorbets E, Steg PG, Young R, Danchin N, Greenlaw $\mathrm{N}$, Ford I, et al. $\beta$-Blockers, calcium antagonists, and mortality in stable coronary artery disease: an international cohort study. Eur Heart J. 2019;40(18):1399-407.
26. Ford TJ, Corcoran D, Berry C. Stable coronary syndromes: pathophysiology, diagnostic advances and therapeutic need. Heart. 2018;104(4):284-92.

27. National Institute for Clinical Excellence. Stable angina management-clinical guideline CG126. https://www.nice.org.uk/guidance/cg126/ chapter/1-Guidance\#anti-anginal-drug-treatment.

28. Ferrari R, Pavasini R, Censi S, Squeri A, Rosano G. The new ESC guidelines for the diagnosis and management of chronic coronary syndromes: the good and the not so good. Curr Probl Cardiol. 2020: 100554 .

29. Ferrari R, Rosano G. "2019 Guidelines for the Diagnosis and Management of Chronic Coronary Syndromes": congratulations and tribulations. Eur Heart J Cardiovasc Pharmacother. 2020.

30. Ambrosio G, Mugelli A, Lopez-Sendon J, Tamargo J, Camm J. Management of stable angina: a commentary on the European Society of Cardiology guidelines. Eur J Prev Cardiol. 2016;23(13):1401-12.

31. Manolis AJ, Poulimenos LE, Ambrosio G, Kallistratos MS, Lopez-Sendon J, Dechend R, et al. Medical treatment of stable angina: a tailored therapeutic approach. Int J Cardiol. 2016;220: 445-53.

32. Iona Study Group. Effect of nicorandil on coronary events in patients with stable angina: the Impact Of Nicorandil in Angina (IONA) randomised trial. Lancet. 2002;359(9314):1269-75.

33. Ford TJ, Stanley B, Good R, Rocchiccioli P, McEntegart M, Watkins S, et al. Stratified medical therapy using invasive coronary function testing in angina. The CorMicA Trial. 2018;72(23 Part A): 2841-55.

34. Bangalore S, Steg G, Deedwania P, Crowley K, Eagle $\mathrm{KA}$, Goto $\mathrm{S}$, et al. $\beta$-Blocker use and clinical outcomes in stable outpatients with and without coronary artery disease. JAMA. 2012;308(13): 1340-9.

35. Fox K, Ford I, Steg PG, Tardif JC, Tendera M, Ferrari $\mathrm{R}$, et al. Ivabradine in stable coronary artery disease without clinical heart failure. $\mathrm{N}$ Engl J Med. 2014;371(12):1091-9.

36. Fox K, Ford I, Steg PG, Tendera M, Ferrari R, BEAUTIFUL Investigators. Ivabradine for patients with stable coronary artery disease and left-ventricular systolic dysfunction (BEAUTIFUL): a randomised, double-blind, placebo-controlled trial. Lancet. 2008;372(9641):807-16.

37. Salazar CA, Basilio Flores JE, Veramendi Espinoza LE, Mejia Dolores JW, Rey Rodriguez DE, Loza 
Munarriz C. Ranolazine for stable angina pectoris. Cochrane Database Syst Rev. 2017;2:CD011747.

38. Morrow DA, Scirica BM, Karwatowska-Prokopczuk E, Murphy SA, Budaj A, Varshavsky S, et al. Effects of ranolazine on recurrent cardiovascular events in patients with non-ST-elevation acute coronary syndromes: the MERLIN-TIMI 36 randomized trial. JAMA. 2007;297(16):1775-83.

39. Belsey J, Savelieva I, Mugelli A, Camm AJ. Relative efficacy of antianginal drugs used as add-on therapy in patients with stable angina: a systematic review and meta-analysis. Eur J Prev Cardiol. 2015;22(7): 837-48.

40. Heidenreich PA, McDonald KM, Hastie T, Fadel B, Hagan V, Lee BK, et al. Meta-analysis of trials comparing beta-blockers, calcium antagonists, and nitrates for stable angina. JAMA. 1999;281(20): 1927-36.

41. Tarkin JM, Kaski JC. Nicorandil and long-acting nitrates: vasodilator therapies for the management of chronic stable angina pectoris. Eur Cardiol. 2018;13(1):23-8.

42. Knorr M, Hausding M, Kröller-Schuhmacher S, Steven S, Oelze M, Heeren $\mathrm{T}$, et al. Nitroglycerin-induced endothelial dysfunction and tolerance involve adverse phosphorylation and s-glutathionylation of endothelial nitric oxide synthase. Arterioscler Thromb Vasc Biol. 2011;31(10): 2223-31.

43. Thomas GR, DiFabio JM, Gori T, Parker JD. Once daily therapy with isosorbide-5-mononitrate causes endothelial dysfunction in humans: evidence of a free-radical-mediated mechanism. J Am Coll Cardiol. 2007;49(12):1289-95.

44. Azevedo ER, Schofield AM, Kelly S, Parker JD. Nitroglycerin withdrawal increases endotheliumdependent vasomotor response to acetylcholine. J Am Coll Cardiol. 2001;37(2):505-9.

45. Caramori PR, Adelman AG, Azevedo ER, Newton GE, Parker AB, Parker JD. Therapy with nitroglycerin increases coronary vasoconstriction in response to acetylcholine. J Am Coll Cardiol. 1998;32(7): 1969-74.

46. Münzel T, Mollnau H, Hartmann M, Geiger C, Oelze M, Warnholtz A, et al. Effects of a nitrate-free interval on tolerance, vasoconstrictor sensitivity and vascular superoxide production. J Am Coll Cardiol. 2000;36(2):626-34.

47. Munzel T, Daiber A, Gori T. Nitrate therapy: new aspects concerning molecular action and tolerance. Circulation. 2011;123(19):2132-44.
48. Ishikawa K, Kanamasa K, Ogawa I, Takenaka $\mathrm{T}$, Naito T, Kamata N, et al. Long-term nitrate treatment increases cardiac events in patients with healed myocardial infarction. Secondary Prevention Group. Jpn Circ J. 1996;60(10):779-88.

49. Kim CH, Park TK, Cho SW, Oh MS, Lee DH, Seong $\mathrm{CS}$, et al. Impact of different nitrate therapies on long-term clinical outcomes of patients with vasospastic angina: a propensity score-matched analysis. Int J Cardiol. 2018;252:1-5.

50. Nakamura Y, Moss AJ, Brown MW, Kinoshita M, Kawai C. Long-term nitrate use may be deleterious in ischemic heart disease: a study using the databases from two large-scale postinfarction studies. Multicenter Myocardial Ischemia Research Group. Am Heart J. 1999;138(3):577-85.

51. Takahashi J, Nihei T, Takagi Y, Miyata S, Odaka Y, Tsunoda R, et al. Prognostic impact of chronic nitrate therapy in patients with vasospastic angina: multicentre registry study of the Japanese coronary spasm association. Eur Heart J. 2015;36(4):228-37.

52. Camici PG, Crea F. Coronary microvascular dysfunction. N Engl J Med. 2007;356(8):830-40.

53. Hirohata A, Yamamoto K, Hirose E, Kobayashi Y, Takafuji H, Sano F, et al. Nicorandil prevents microvascular dysfunction resulting from PCI in patients with stable angina pectoris: a randomised study. EuroIntervention. 2014;9(9):1050-6.

54. Zhu H, Xu X, Fang X, Zheng J, Zhao Q, Chen T, et al. Effects of the antianginal drugs ranolazine, nicorandil, and ivabradine on coronary microvascular function in patients with nonobstructive coronary artery disease: a meta-analysis of randomized controlled trials. Clin Ther. 2019.

55. Herman AG, Moncada S. Therapeutic potential of nitric oxide donors in the prevention and treatment of atherosclerosis. Eur Heart J. 2005;26(19): 1945-55.

56. European Medicines Agency. Questions and answers on Ikorel, Dancor and associated names (nicorandil, 10 and $20 \mathrm{mg}$ tablets). Outcome of a procedure under Article 30 of Directive 2001/83/EC. 2015.

57. Kukovetz WR, Holzmann S, Poch G. Molecular mechanism of action of nicorandil. J Cardiovasc Pharmacol. 1992;20(Suppl 3):S1-7.

58. Paravastu SC, Mendonca DA, Da Silva A. Beta blockers for peripheral arterial disease. Cochrane Database Syst Rev. 2013(9):CD005508.

59. Sakai K, Shiraki Y, Nabata H. Cardiovascular effects of a new coronary vasodilator N-(2- 
hydroxyethyl)nicotinamide nitrate (SG-75): comparison with nitroglycerin and diltiazem. J Cardiovasc Pharmacol. 1981;3(1):139-50.

60. Suryapranata H, Serruys PW, De Feyter PJ, Verdouw PD, Hugenholtz PG. Coronary vasodilatory action after a single dose of nicorandil. Am J Cardiol. 1988;61(4):292-7.

61. Krumenacker M, Roland E. Clinical profile of nicorandil: an overview of its hemodynamic properties and therapeutic efficacy. J Cardiovasc Pharmacol. 1992;20(Suppl 3):S93-102.

62. Matsubara T, Minatoguchi S, Matsuo H, Hayakawa $\mathrm{K}$, Segawa T, Matsuno Y, et al. Three minute, but not one minute, ischemia and nicorandil have a preconditioning effect in patients with coronary artery disease. J Am Coll Cardiol. 2000;35(2): 345-51.

63. Sato T, Sasaki N, O'Rourke B, Marban E. Nicorandil, a potent cardioprotective agent, acts by opening mitochondrial ATP-dependent potassium channels. J Am Coll Cardiol. 2000;35(2):514-8.

64. Cavero I, Djellas Y, Guillon JM. Ischemic myocardial cell protection conferred by the opening of ATP-sensitive potassium channels. Cardiovasc Drugs Ther. 1995;9(Suppl 2):245-55.

65. Markham A, Plosker GL, Goa KL. Nicorandil. An updated review of its use in ischaemic heart disease with emphasis on its cardioprotective effects. Drugs. 2000;60(4):955-74.

66. Hausenloy DJ, Maddock HL, Baxter GF, Yellon DM. Inhibiting mitochondrial permeability transition pore opening: a new paradigm for myocardial preconditioning? Cardiovasc Res. 2002;55(3):534-43.

67. Szewczyk A, Marban E. Mitochondria: a new target for $\mathrm{K}$ channel openers? Trends Pharmacol Sci. 1999;20(4):157-61.

68. He W, Su Q, Liang J, Sun Y, Wang X, Li L. The protective effect of nicorandil on cardiomyocyte apoptosis after coronary microembolization by activating Nrf2/HO-1 signaling pathway in rats. Biochem Biophys Res Commun. 2018;496(4): 1296-301.

69. Wu H, Ye M, Yang J, Ding J, Yang J, Dong W, et al. Nicorandil protects the heart from ischemia/reperfusion injury by attenuating endoplasmic reticulum response-induced apoptosis through PI3K/Akt signaling pathway. Cell Physiol Biochem. 2015;35(6): 2320-32.

70. Izumiya Y, Kojima S, Kojima S, Araki S, Usuku H, Matsubara J, et al. Long-term use of oral nicorandil stabilizes coronary plaque in patients with stable angina pectoris. Atherosclerosis. 2011;214(2): 415-21.

71. Jaraki O, Strauss WE, Francis S, Loscalzo J, Stamler JS. Antiplatelet effects of a novel antianginal agent, nicorandil. J Cardiovasc Pharmacol. 1994;23(1): 24-30.

72. Sekiya M, Sato M, Funada J, Ohtani T, Akutsu H, Watanabe K. Effects of the long-term administration of nicorandil on vascular endothelial function and the progression of arteriosclerosis. J Cardiovasc Pharmacol. 2005;46(1):63-7.

73. Frydman A. Pharmacokinetic profile of nicorandil in humans: an overview. J Cardiovasc Pharmacol. 1992;20(Suppl 3):S34-44.

74. Frydman AM, Chapelle P, Diekmann H, Bruno R, Thebault JJ, Bouthier J, et al. Pharmacokinetics of nicorandil. Am J Cardiol. 1989;63(21):25J-33J.

75. Molinaro M, Villa G, Regazzi MB, Salvadeo A, Segagni S, Rondanelli R, et al. Pharmacokinetics of nicorandil in patients with normal and impaired renal function. Eur J Clin Pharmacol. 1992;42(2): 203-7.

76. Wagner G. Selected issues from an overview on nicorandil: tolerance, duration of action, and longterm efficacy. J Cardiovasc Pharmacol. 1992;20(Suppl 3):S86-92.

77. Kool MJ, Spek JJ, Struyker Boudier HA, Hoeks AP, Reneman RS, van Herwaarden RH, et al. Acute and subacute effects of nicorandil and isosorbide dinitrate on vessel wall properties of large arteries and hemodynamics in healthy volunteers. Cardiovasc Drugs Ther. 1995;9(2):331-7.

78. Camm AJ, Maltz MB. A controlled single-dose study of the efficacy, dose response and duration of action of nicorandil in angina pectoris. Am J Cardiol. 1989;63(21):61J-65J.

79. Hayata N, Araki H, Nakamura M. Effects of nicorandil on exercise tolerance in patients with stable effort angina: a double-blind study. Am Heart J. 1986;112(6):1245-50.

80. Kinoshita M, Nishikawa S, Sawamura M, Yamaguchi $\mathrm{S}$, Mitsunami K, Itoh M, et al. Comparative efficacy of high-dose versus low-dose nicorandil therapy for chronic stable angina pectoris. Am J Cardiol. 1986;58(9):733-8.

81. Meany TB, Richardson P, Camm AJ, Coltart J, Griffith M, Maltz MB, et al. Exercise capacity after single and twice-daily doses of nicorandil in chronic stable angina pectoris. Am J Cardiol. 1989;63(21): $66 \mathrm{~J}-70 \mathrm{~J}$. 
82. Ciampricotti R, Schotborgh C, de Kam PJ, van Herwaarden R. A comparison of nicorandil with isosorbide mononitrate in elderly patients with stable coronary heart disease: the SNAPE study. Am Heart J. 2000;139:e1-9.

83. Doring G. Antianginal and anti-ischemic efficacy of nicorandil in comparison with isosorbide-5mononitrate and isosorbide dinitrate: results from two multicenter, double-blind, randomized studies with stable coronary heart disease patients. J Cardiovasc Pharmacol. 1992;20(Suppl 3):S74-81.

84. Lai C, Onnis E, Solinas R, Orani E, Lai G, Cadeddu $\mathrm{M}$, et al. A new anti-ischemic drug for the treatment of stable effort angina pectoris: nicorandil. Comparison with placebo and isosorbide-5-mononitrate. Cardiologia. 1991;36(9):703-11.

85. Falcone C, Auguardro C. A double blind comparison of nicorandil and isosorbide dinitrate slow release in patients with stable angina pectoris [abstract]. Eur Heart J. 1993;14:376.

86. Zhu WL, Shan YD, Guo JX, Wei JP, Yang XC, Li TD, et al. Double-blind, multicenter, active-controlled, randomized clinical trial to assess the safety and efficacy of orally administered nicorandil in patients with stable angina pectoris in China. Circ J. 2007;71(6):826-33.

87. Di Somma S, Liguori V, Petitto M, Carotenuto A, Bokor D, de Divitiis O, et al. A double-blind comparison of nicorandil and metoprolol in stable effort angina pectoris. Cardiovasc Drugs Ther. 1993;7(1): 119-23.

88. Hughes LO, Rose EL, Lahiri A, Raftery EB. Comparison of nicorandil and atenolol in stable angina pectoris. Am J Cardiol. 1990;66(7):679-82.

89. Meeter K, Kelder JC, Tijssen JG, Bucx JJ, Henneman JA, Kerker JP, et al. Efficacy of nicorandil versus propranolol in mild stable angina pectoris of effort: a long-term, double-blind, randomized study. J Cardiovasc Pharmacol. 1992;20(Suppl 3):S59-66.

90. Raftery EB, Lahiri A, Hughes LO, Rose EL. A doubleblind comparison of a beta-blocker and a potassium channel opener in exercise induced angina. Eur Heart J. 1993;14(Suppl B):35-9.

91. Guermonprez JL, Blin P, Peterlongo F. A doubleblind comparison of the long-term efficacy of a potassium channel opener and a calcium antagonist in stable angina pectoris. Eur Heart J. 1993;14(Suppl B):30-4.

92. Horinaka S, Yabe A, Yagi H, Ishimitsu T, Yamazaki T, Suzuki S, et al. Effects of nicorandil on cardiovascular events in patients with coronary artery disease in the Japanese Coronary Artery Disease (JCAD) study. Circ J. 2010;74(3):503-9.

93. SWAN Study Group. Comparison of the antiischaemic and antianginal effects of nicorandil and amlodipine in patients with symptomatic stable angina pectoris: the SWAN study. J Clin Basic Cardiol. 1999;2:213-7.

94. Ulvenstam G, Diderholm E, Frithz G, Gudbrandsson T, Hedback B, Hoglund C, et al. Antianginal and anti-ischemic efficacy of nicorandil compared with nifedipine in patients with angina pectoris and coronary heart disease: a double-blind, randomized, multicenter study. J Cardiovasc Pharmacol. 1992;20(Suppl 3):S67-73.

95. Lesnefsky EJ. The IONA study: preparing the myocardium for ischaemia? Lancet. 2002;359(9314): 1262-3.

96. Iona Study Group. Impact of nicorandil in angina: subgroup analyses. Heart. 2004;90(12):1427-30.

97. Walker A, McMurray J, Stewart S, Berger W, McMahon AD, Dargie H, et al. Economic evaluation of the impact of nicorandil in angina (IONA) trial. Heart. 2006;92(5):619-24.

98. Luo B, Wu P, Bu T, Zeng Z, Lu D. All-cause mortality and cardiovascular events with nicorandil in patients with IHD: systematic review and metaanalysis of the literature. Int J Cardiol. 2014;176(3): 661-9.

99. Jiang J, Li Y, Zhou Y, Li X, Li H, Tang B, et al. Oral nicorandil reduces ischemic attacks in patients with stable angina: a prospective, multicenter, openlabel, randomized, controlled study. Int J Cardiol. 2016;224:183-7.

100. Kishida H, Murao S. Effect of a new coronary vasodilator, nicorandil, on variant angina pectoris. Clin Pharmacol Ther. 1987;42(2):166-74.

101. Picard F, Sayah N, Spagnoli V, Adjedj J, Varenne O. Vasospastic angina: a literature review of current evidence. Arch Cardiovasc Dis. 2019;112(1):44-55.

102. Chen JW, Lee WL, Hsu NW, Lin SJ, Ting CT, Wang SP, et al. Effects of short-term treatment of nicorandil on exercise-induced myocardial ischemia and abnormal cardiac autonomic activity in microvascular angina. Am J Cardiol. 1997;80(1):32-8.

103. Ito N, Nanto S, Doya Y, Kurozumi Y, Natsukawa T, Shibata $\mathrm{H}$, et al. Beneficial effects of intracoronary nicorandil on microvascular dysfunction after primary percutaneous coronary intervention: demonstration of its superiority to nitroglycerin in a crossover study. Cardiovasc Drugs Ther. 2013;27(4): 279-87. 
104. Russo G, Di Franco A, Lamendola P, Tarzia P, Nerla $\mathrm{R}$, Stazi A, et al. Lack of effect of nitrates on exercise stress test results in patients with microvascular angina. Cardiovasc Drugs Ther. 2013;27(3):229-34.

105. Jia Q, Shi S, Yuan G, Shi J, Shi S, Wei Y, et al. The effect of nicorandil in patients with cardiac syndrome X: a meta-analysis of randomized controlled trials. Medicine. 2020;99(37):e22167.

106. Uren NG, Crake T, Lefroy DC, de Silva R, Davies GJ, Maseri A. Delayed recovery of coronary resistive vessel function after coronary angioplasty. J Am Coll Cardiol. 1993;21(3):612-21.

107. Crea F, Bairey Merz CN, Beltrame JF, Berry C, Camici PG, Kaski JC, et al. Mechanisms and diagnostic evaluation of persistent or recurrent angina following percutaneous coronary revascularization. Eur Heart J. 2019;40(29):2455-62.

108. Ferrari R, Ford I, Fox K, Challeton JP, Correges A, Tendera $\mathrm{M}$, et al. Efficacy and safety of trimetazidine after percutaneous coronary intervention (ATPCI): a randomised, double-blind, placebo-controlled trial. Lancet. 2020;396(10254):830-8.

109. Weisz G, Généreux P, Iñiguez A, Zurakowski A, Shechter M, Alexander KP, et al. Ranolazine in patients with incomplete revascularisation after percutaneous coronary intervention (RIVER-PCI): a multicentre, randomised, double-blind, placebocontrolled trial. Lancet. 2016;387(10014):136-45.

110. Ye Z, Su Q, Li L. The clinical effect of nicorandil on perioperative myocardial protection in patients undergoing elective PCI: a systematic review and meta-analysis. Sci Rep. 2017;7:45117.

111. Zhao XT, Zhang CF, Liu QJ. Meta-analysis of Nicorandil effectiveness on myocardial protection after percutaneous coronary intervention. BMC Cardiovasc Disord. 2019;19(1):144.

112. Sara JD, Taher R, Kolluri N, Vella A, Lerman LO, Lerman A. Coronary microvascular dysfunction is associated with poor glycemic control amongst female diabetics with chest pain and non-obstructive coronary artery disease. Cardiovasc Diabetol. $2019 ; 18(1): 22$.
113. Impact of nicorandil in angina: subgroup analyses. Heart. 2004;90(12):1427-30.

114. Sakai K, Kuromaru O. Nitrate tolerance: comparison of nicorandil, isosorbide dinitrate, and nitroglycerin in anesthetized dogs. J Cardiovasc Pharmacol. 1987;10(Suppl 8):S17-24.

115. Henry PJ, Horowitz JD, Louis WJ. Nitrate tolerance induced by nicorandil or nitroglycerin is associated with minimal loss of nicorandil vasodilator activity. J Cardiovasc Pharmacol. 1990;15(3):365-70.

116. Rajaratnam R, Brieger DB, Hawkins R, Freedman SB. Attenuation of anti-ischemic efficacy during chronic therapy with nicorandil in patients with stable angina pectoris. Am J Cardiol. 1999;83(7): 1120-4, a9.

117. Ito $\mathrm{H}$, Taniyama $\mathrm{Y}$, Iwakura $\mathrm{K}$, Nishikawa $\mathrm{N}$, Masuyama T, Kuzuya $\mathrm{T}$, et al. Intravenous nicorandil can preserve microvascular integrity and myocardial viability in patients with reperfused anterior wall myocardial infarction. J Am Coll Cardiol. 1999;33(3):654-60.

118. Okamura A, Rakugi H, Ohishi M, Yanagitani Y, Shimizu M, Nishii T, et al. Additive effects of nicorandil on coronary blood flow during continuous administration of nitroglycerin. J Am Coll Cardiol. 2001;37(3):719-25.

119. Li Y, Liu Y, Peng W, Wang B, Geng T, Xu Z. Therapeutic effect and safety of nicorandil in treatment of refractory angina pectoris. Int J Clin Exp Med. 2018;11(7):6993-8.

120. Zeng L, Chen X, Wen Y, Chun L. Clinical study of isosorbide mononitrate combined with nicorandil in treatment of type 2 diabetic patients with stable angina pectoris. World Phytomedicines. 2016;1:54-8.

121. Fihn SD, Blankenship JC, Alexander KP, Bittl JA, Byrne JG, Fletcher BJ, et al. 2014 ACC/AHA/AATS/ PCNA/SCAI/STS focused update of the guideline for the diagnosis and management of patients with stable ischemic heart disease. Circulation. 2014;130(19):1749-67. 